\title{
Evaluating $\mathrm{NH}_{3}-\mathrm{N}$ Pollution Load of Weihe River Watershed above TongGuan Section by Characteristic Section Load Method
}

\author{
Lei Zhu ${ }^{1,2}$, JinXi Song ${ }^{1,2}$, WanQing Liu ${ }^{1}$ \\ ${ }^{1}$ College of Urban and Environmental Sciences, Northwest University, Xl'an 710127, China \\ ${ }^{2}$ Shaanxi Key Laboratory of Earth Surface System and Environmental Carrying Capacity, Xl'an \\ 710127, China \\ woulda@163.com
}

Keywords: Weihe River; TongGuan Section; non-point source pollution; CLSD method

\begin{abstract}
TongGuan Section of Weihe River Watershed is a provincial section between Shaanxi Province and Henan Province, China. So it is taken as the research objective in this paper and $\mathrm{NH}_{3}-\mathrm{N}$ is chosen as the water quality parameter. According to the discharge characteristics of point source pollutions and non-point source pollutions, a method to estimate pollution loads characteristic section load (CSLD) method is suggested and point and non-point source pollution loads of Weihe River Watershed above TongGuan Section are calculated in the rainy, normal and dry season in the year 2013. The results show that the monthly point source pollution loads of Weihe River Watershed above TongGuan Section discharge stably and the monthly non-point source pollution loads of Weihe River Watershed above TongGuan Section change greatly. The non-point source pollution load proportions of total pollution load of $\mathrm{NH}_{3}-\mathrm{N}$ decrease in the wet, normal and rainy period in turn.
\end{abstract}

\section{Introduction}

Since the occurrences of non-point source pollution are random, and pollution load vary widely in time and space, those bring much difficulty to calculate of non -point source pollution load. Because the point source pollutions are gradually under control, non-point source pollution problems of river basins are increasingly prominent. There are many relatively comprehensive, advanced methods can be used to estimate non-point source pollution load, such as runoff segmentation method ${ }^{[1]}$, export coefficient method ${ }^{[2]}$, water quality \& quantity method ${ }^{[3]}$, rainfall deduction method ${ }^{[4]}$, mean concentration method ${ }^{[5]}$ and etc. But these parameters are numerous, and some parameter measurements are difficult to obtain ${ }^{[6]}$. In this paper, according to the characteristics of point source pollution and non-point source pollution, a method-characteristic section load (CSLD) method is proposed to estimate $\mathrm{NH}_{3}-\mathrm{N}$ pollution load. Weihe River Watershed above TongGuan Section is chosen as the research object. The point and non-point source pollution loads in the rainy, normal and dry season are calculated in the year 2013. TongGuan Section of Weihe River Watershed is a provincial section between Shaanxi Province and Henan Province, China. The quantitative computing of pollutant loads is the basis of researches on environmental problems such as improving water quality.

\section{Research Methods}

How to estimate the amount of non-point source pollution load based on limited information has become an important basis for the prediction of water quality and water quality planning. Since monitoring non-point source pollution is difficult and costs high, there is almost no continuous monitoring data in China. The characteristic section load method is a method to estimate annual pollutant emissions which based on the characteristics of the point and non-point source pollution. Non-point source pollutants enter the surface water and groundwater in a form of wide-dispersion areas and traces. Such pollution loads are very huge with a great randomness, uncertainty and complexity and influenced by the external climate and hydrological conditions in a large extent. Point source pollution includes the fixed outfall discharge of city life sewage and industrial wastewater mainly. In a particular year the urban population doesn't change significantly and the monthly emissions of pollutants in urban living are relatively stable while industrial waste water 
amount changes a little in a year. The point source pollutant discharge is relatively stable. Since the non-point source pollution loads vary largely in a year and calculating the total pollution loads is relatively easy and simple, the non-point source pollution load estimation can be obtained indirectly in the way that the total pollution loads minus the watershed point source pollution loads. Rainfall runoff is the main reason for the non-point source pollution in a watershed. In the dry season the basin has little rain and the pollutants load is mainly point source pollution load. Above the river characteristic section, the monthly basin point pollution load $L_{p p m}$ can be determined by the minimum value of the average concentration $C_{i}$ multiplied the average flow $W_{i}$ in the dry season.

$$
L_{p p m}=\operatorname{Min}\left(C_{i} W_{i}\right)
$$

The monthly river basin pollution total load $L_{t m}$ is determined by the monthly water quality concentration $C_{i}$ multiplied the average monthly flow $W_{i}$ of the characteristics section.

$$
L_{t m}=C_{i}^{*} W_{i}
$$

The monthly river basin non-point source pollution load $L_{n p p m}$ equals the monthly total watershed pollution load $L_{t m}$ minus the monthly basin point source pollution load $L_{p p m}$

$$
L_{n p p m}=L_{t m}-L_{p p m}
$$

The yearly basin point source load $L_{p p y}$ can be counted by

$$
L_{p p y}=12 * \operatorname{Min}\left(C_{i}^{*} W_{i}\right)
$$

The yearly basin point source total load $L_{t y}$ can be computed by

$$
L_{t y}=\sum_{i=1}^{12} C_{i}^{*} W_{i}
$$

The yearly basin non- point source load $L_{n p p y}$ can be calculated by

$$
L_{\text {nppy }}=L_{t y}-L_{\text {ppy }}
$$

The characteristic section load method is applied to estimate the pollution load of Weihe River Basin above TongGuan Section. $\mathrm{NH}_{3}-\mathrm{N}$ is the water quality parameter. The year 2013 is selected as the current year. The water phase is divided as follows: July, August, September and October are wet periods. April, May, June and November are flat water periods. January, February, March and December are dry seasons.

The river flow changes of TongGuan Section in the year 2013 are shown in figure 1.

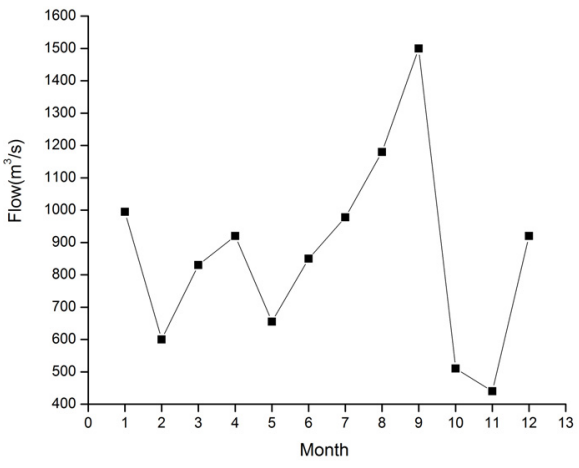

Fig.1 Flow changes of TongGuan Section in 2013

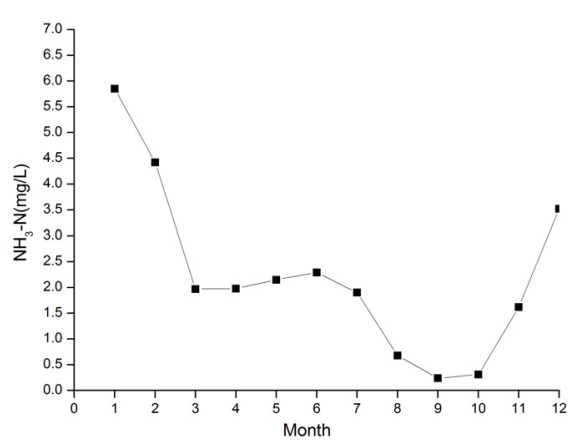

Fig. $2 \mathrm{NH}_{3}-\mathrm{N}$ concentration changes in 2013

As can be seen from Figure 1, the maximum flow of TongGuan Section is $1500.00 \mathrm{~m}^{3} / \mathrm{s}$ in September and the minimum flow is $440.00 \mathrm{~m}^{3} / \mathrm{s}$ in November. Average monthly flows in January, April and December are $995.00 \mathrm{~m}^{3} / \mathrm{s}, 920.00 \mathrm{~m}^{3} / \mathrm{s}$ and $920.00 \mathrm{~m}^{3} / \mathrm{s}$ respectively. Average monthly flows in February and May are $600.00 \mathrm{~m}^{3} / \mathrm{s}$ and $655.00 \mathrm{~m}^{3} / \mathrm{s}$ respectively. The annual average flow is about $864.83 \mathrm{~m}^{3} / \mathrm{s}$. The average flow is $1042.00 \mathrm{~m}^{3} / \mathrm{s}$ in the wet period, $716.25 \mathrm{~m}^{3} / \mathrm{s}$ and 836.25 $\mathrm{m}^{3} / \mathrm{s}$ in the normal and dry season.

The $\mathrm{NH}_{3}-\mathrm{N}$ concentration changings of Weihe River Watershed above TongGuan Section in the year 2013 are shown in figure 2. As can be seen from Figure 2, the maximum of $\mathrm{NH}_{3}-\mathrm{N}$ concentration is $5.85 \mathrm{mg} / \mathrm{L}$ in January and the minimum is $0.24 \mathrm{mg} / \mathrm{L}$ in September. The annual average concentration is about $2.24 \mathrm{mg} / \mathrm{L}$. The $\mathrm{NH}_{3}-\mathrm{N}$ concentration is $0.78 \mathrm{mg} / \mathrm{L}, 2.01 \mathrm{mg} / \mathrm{L}$ and 
$3.94 \mathrm{mg} / \mathrm{L}$ in the wet, normal and dry season respectively.

\section{Results}

The equations (1) to (6) of characteristic section load method are used to calculate the $\mathrm{NH}_{3}-\mathrm{N}_{\text {point }}$ source and non-point source pollution load. The results are shown in Figure 3 and Figure 4.

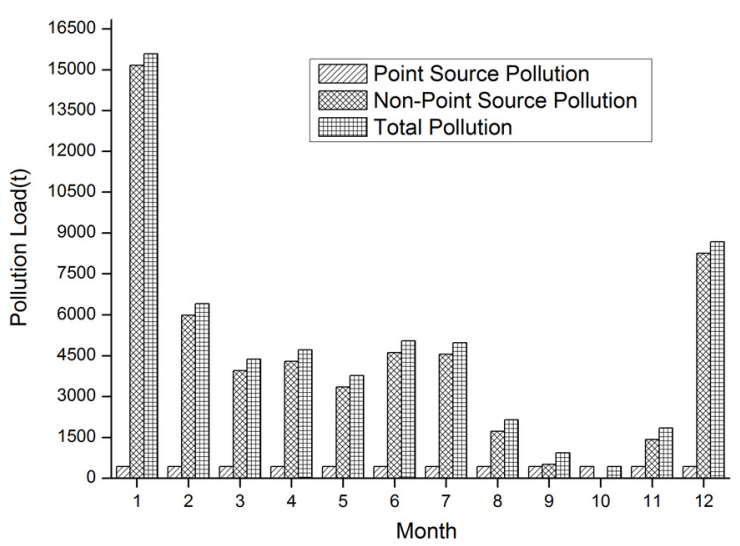

Fig. $3 \mathrm{NH}_{3}-\mathrm{N}$ pollution loads in 2013

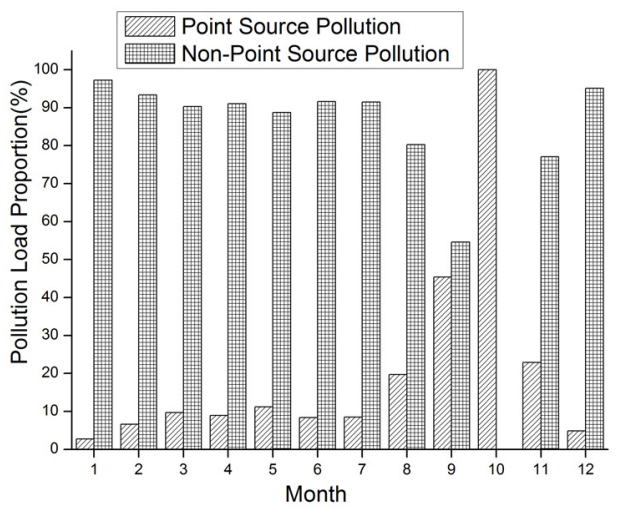

Fig. $4 \mathrm{NH}_{3}-\mathrm{N}$ pollution loads proportion in 2013

As can be seen from Figure 3 and Figure 4, the total annual $\mathrm{NH}_{3}-\mathrm{N}$ discharge is 58928.27 t. Among them, the point source emission is $5081.46 \mathrm{t}$ accounting for $8.62 \%$ of the total annual emissions. The non-point source is $53846.81 \mathrm{t}$ accounting for $91.38 \%$ of the total annual emissions. The $\mathrm{NH}_{3}-\mathrm{N}$ point source pollution load discharge stably in each month and the monthly average load is 423.46 t. Non-point source pollution load emission changes largely in each month. The largest $\mathrm{NH}_{3}-\mathrm{N}$ non-point source pollution load is in the dry period. The total emission is $33365.38 \mathrm{t}$ accounting for $61.96 \%$ of the annual total emissions. Followed is the flat season, total emission is $13692.53 \mathrm{t}$ accounting for $25.43 \%$ of the total annual emissions. The minimum is in the rainy period, the total emission is $6788.91 \mathrm{t}$ accounting for $12.61 \%$ of the total annual emissions.

\section{Conclusions}

This paper established a method- characteristic load method to estimate point and non-point source pollution loads. The $\mathrm{NH}_{3}-\mathrm{N}$ pollution load above TongGuan Section of Weihe River Basin is estimated in the year 2013. The conclusions are following:

1) The point source pollution load discharge stably each month throughout the year above TongGuan Section of Weihe River Basin. $\mathrm{NH}_{3}-\mathrm{N}$ monthly average load is $423.46 \mathrm{t}$ and its annual average load is $5081.46 \mathrm{t}$.

2) The non-point source pollution emissions vary widely each month throughout the year above TongGuan Section of Weihe River Watershed and the annual load is $53846.81 \mathrm{t}$.

3 ) In the rainy, flat and dry season, non-point source pollution load of $\mathrm{NH}_{3}-\mathrm{N}$ proportion accounting for the total pollution load is $12.61 \%, 25.43 \%$ and $61.96 \%$.

\section{Acknowledgements}

This work was financially supported by Natural Science Foundation of Shaanxi Provincial Department of Education (16JK1784), Postdoctoral Science Foundation of Northwest University (BSH13020), Key Science and Technology Innovation Team in Shaanxi Province (2014KCT-27) and Research on Waterlogging and Rainwater Utilization in Rural Areas, Soil and Water Conservation Bureau of Shaanxi Province (1601).

\section{References}

[1] Cai Ming. Nitrogen pollution and its control planning in Shaanxi Reach of Weihe River [D]. Xi'an: Xi'an University of Technology, 2004.

[2] Johns P J. Evaluation and management of the impact of land use change on the nitrogen and phosphorus load delivered to surface waters: the export coefficient modeling approach [J]. J of Hydrology,1996, 183(3):323-349 
[3] Hong Xiaokang, Li Huaien. Correlation Method of Water Quality and Quantity and Its Application to Load Estimation of Nonpoint Source Pollution [J]. Journal of Xi an University of Technology, 2000, 16(4): 384-386.

[4] Cai Ming, Li Huaien, Zhuang Yongtao. Rainfall deduction method for estimating non-point source pollution load for watershed [J]. Journal of Northwest Sci-Tech University of Agriculture and Forestry, 2005, 33(4):102-106.

[5] Li Huaien. Mean concentration method for estimation of nonpoint source load and its application [J]. ACTA SCIENTIAE CIRCUMSTANTIAE, 2000, 20 (4):397-400.

[6] Zhu Lei, Song, Jin Xi, Liang, Li Hua, et al. Applicability analysis on the improved one-dimension steady-state river water quality model [J]. Applied Mechanics and Materials, 2013, 405-408: 2254-2259. 